\title{
Hvad er Danmarks styrke på digital innovation i den finansielle sektor?
}

\author{
Af Loerke Højgaard Christiansen og Lykke Margot Ricard *)
}

\begin{abstract}
Resumé
I denne artikel ser vi nærmere på de strukturelle styrker, der danner grundlaget for Danmarks digitale styrker med udbredelsen af offentlige digitale services og forbrugere, som accelerer i at tage digitale services til sig. Igennem et institutionelt perspektiv fremhæver artiklen nogle af de egenskaber, som karakteriserer digital innovation af bankservices i Danmark. De væsentligste faktorer, som artiklen peger på, er de offentlige investeringer i digital infrastruktur, som skabende troværdige produkter som NEMID-login hos borgere. Vi fremhæver eksempler på dette mellem de etablerede banker på det danske marked og den nye digitale bank Lunar. Artiklens nyskabelse er, at den bidrager med 'bricolage-perspektivet' på nye digitale bankservices, hvor eksisterende ressourcer genanvendes på nye måder og i nye konstellationer gennem partnerskaber. Strukturer som danner grundlag for, at digital innovation kan ske i samarbejder, i netværk og partnerskaber som en form for samarbejdsdrevet entreprenørskab. Artiklen bygger videre på et institutionelt innovationsperspektiv, som tilbyder en ny måde at skildre og forstå nøglen til Danmarks digitale innovation på i et konkurrenceprægede miljø.
\end{abstract}

\section{Emneord}

Samarbejdsdrevet entreprenørskab; digital innovation; institutionel innovation; bricolage; bank

*) Lærke Højgaard Christiansen er Lektor i Strategi, Organisation og Ledelse ved DTU Engineering Technology. Lykke Margot Ricard er Lektor i Innovation, Ledelse og Teknologi på Syddansk Universitet. 


\section{A. Indledning}

\section{Baggrund}

Danmark er et af de mest digitale samfund i verden og den finansielle sektor har i høj grad bidraget til denne udvikling. Alligevel ser politikere ofte til Silicon Valley i USA, som et af de mest innovative hubs inden for opbygning af et innovationscluster. Fra politisk side i Danmark kan man snildt få den opfattelse, at der ses misundelsesværdigt på rollemodeller om entreprenører i en verden, hvor penge om noget er en af de stærkeste drivkræfter på skabelse af en af de mest moderne klondike byer inden for IT- og de digitale teknologigiganter. Samtidig med at danske politikere kigger til de digitale teknologigiganter i Silicon Valley, er det dog paradoksalt, at det er Danmark, som er på forkanten på integration af digital teknolog. Danmark er et af de tre mest digitale samfund i verden jf. Europa-Kommissionen, 2020 (Se figur 1 og 2). 'Digital Economy and Society' Indeks (DESI) er et sammensat indeks, der opsummerer relevante indikatorer for Europas digitale ydeevne og sporer udviklingen i EU-medlemsstater i digital konkurrenceevne. Undersøgelsen er mål på fem parametre: Internet adgang, human kapital (uddannelse), anvendelse af Internet, Integration af digital teknologi og offentlige digitale service.

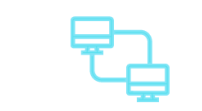

CONNECTIVITY

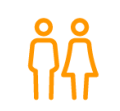

HUMAN CAPITAL

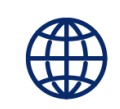

USE OF INTERNET

SERVICES

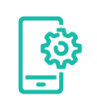

INTEGRATION OF DIGITAL TECHNOLOGY

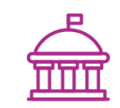

DIGITAL PUBLIC SERVICES

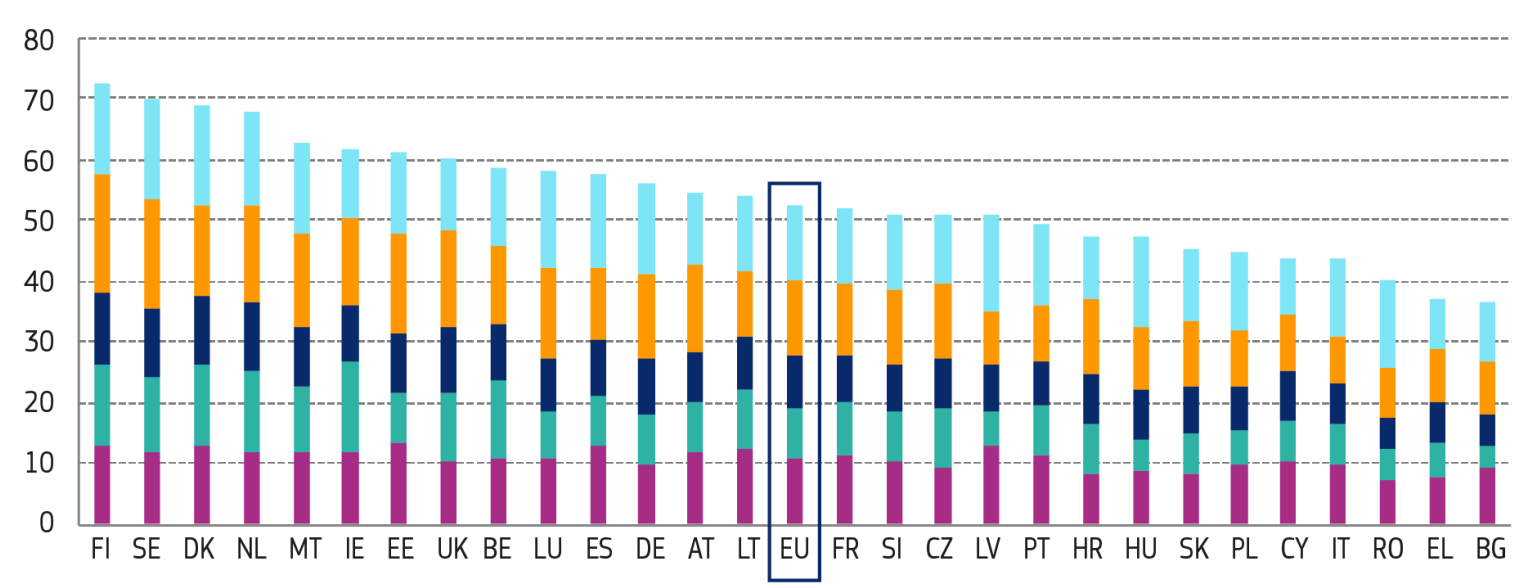

Figur 1: De Digital Økonomier og Samfund, jf. Europa-Kommissionen's DESI indeks (2020) 


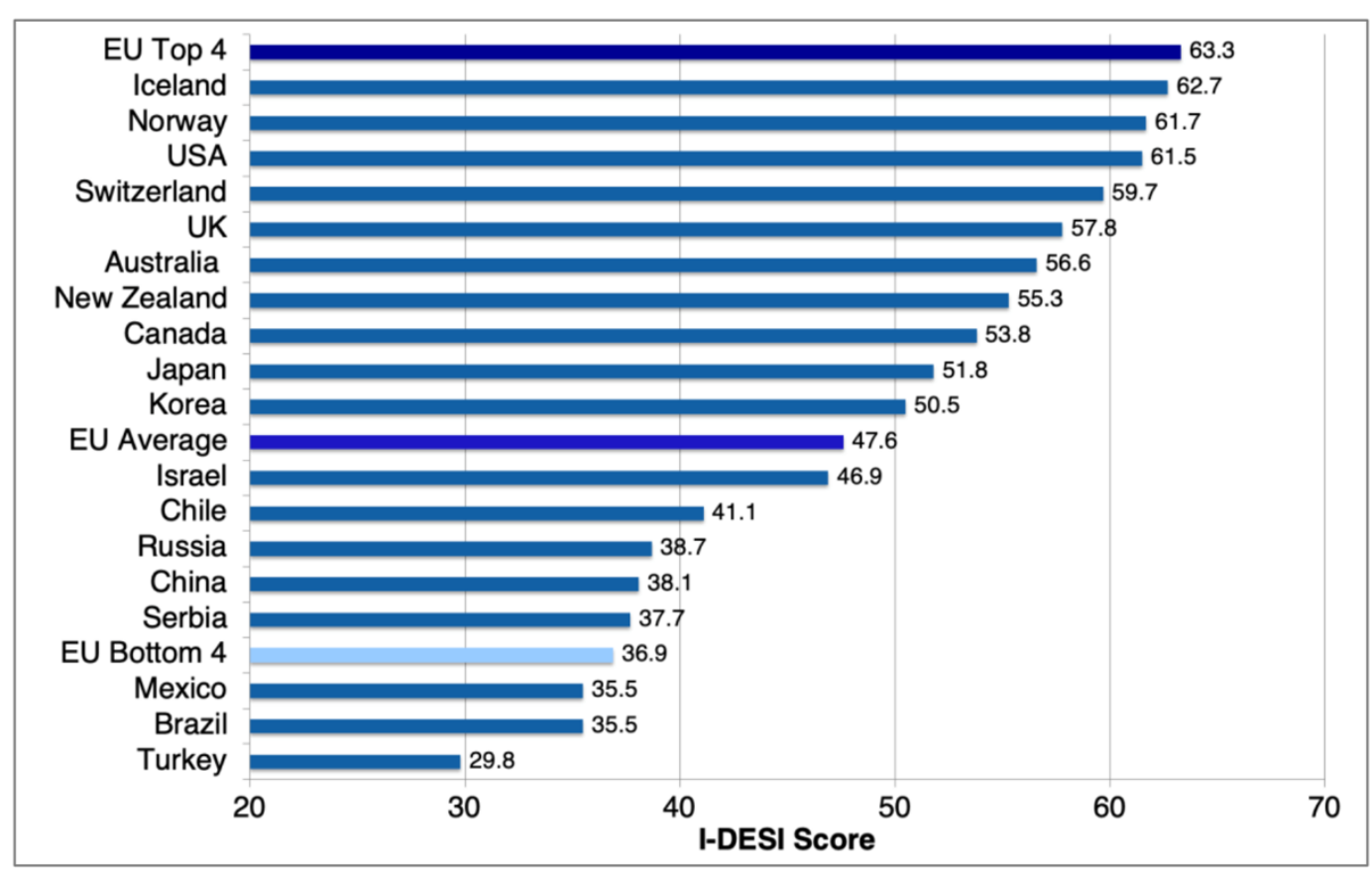

Figur 2: Gennemsnitlig normaliserede score for udvalgte ikke-EU lande på International Digital Economy and Society Index (2020)

I EU's DESI-indeks lå Danmark i 2017 på en førsteplads, men er tre år senere indhentet af Finland og Sverige (men stadig blandt EU's top 4 og foran USA). Danmark er indhentet af de to skandinaviske søstre over de seneste tre år - dog på marginalerne, som på de offentlige digitale services, hvor forspringet er udlignet - og på human kapital, dvs. uddannelse i IT og digitale kompetencer, hvor de to lande accelerer. En vigtig supplerende forklaring på, at Danmark ligger blandt de fire bedste i Europa, må tillægges borgerne. Danskere tager langt hurtigere digitale bankservices til sig end vores Europæiske kollegaer. Danske borgere og 'forbrugere' ligger i top, når det kommer til at tage de digitale services til sig. I Figur 3 ses et billede af accelerationen i danskernes anvendelse af de fire mest anvendte digitale bankservices, hvor kontaktløs betaling via smartphone (i butikker og supermarkeder) er gået endnu stærkere end Mobilpay og Netbank (tallene er fra 2019). 


\section{Danskerne tager hurtigere og hurtigere ny teknologi til sig}

Hvor lang tid det har taget for nye løsninger at nå tre mio. forbrugere:

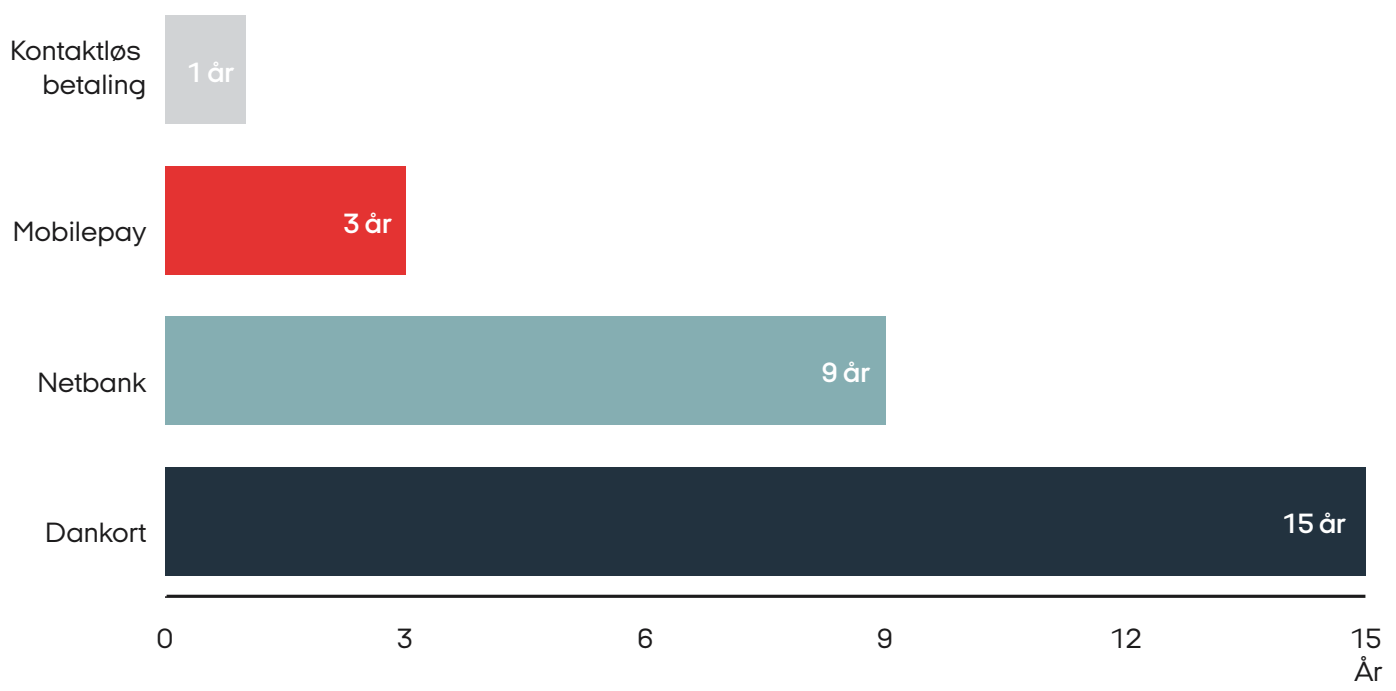

Kilde: Nets, MobilePay, Danmarks Statistik og Finans Danmark

Figur 3: Danskere tager hurtigere og hurtigere ny teknologi til sig

\section{Problemstilling}

Ud af en befolkning på ca. 5.6 millioner, så er der over 4 millioner private brugere af MobilePay i Danmark (Finans Danmark, 2019). Opbygningen af netbank og mobilbank, samt bankernes bidrag til udviklingen af NemID gør, at borgere har tillid til, at man sikkert og nemt kan servicere sig selv online - samtidig med, at den digitale teknologi er integreret til andre services som id-pas, som muliggøre interaktion med det offentlige borgerservice hos kommuner, webbank og pensionsoversigter med mere. Som kontrast anvender man i USA stadig checks til lønoverførsler og betalinger - og det lyder jo helt oldnordisk. I 2019 er der investeret over en milliard danske kroner i danske fintechs virksomheder herhjemme (TechSavvvy, 2019). Men hvad er det, som er kendetegnet for, hvad der sker i Danmark og som gør, at vi er på forkant med den digitale omstilling? Det er vores undren, som resulterer i forskningsspørgsmålet: Ud fra et institutionelt perspektiv, hvad karakteriserer nogle af de væsentligste processer og strukturer omkring digital innovation i Danmark? Igennem rapporter og ekspertinterview, det ene med en etableret interesseorganisation, som en repræsentationsaktør for bank, realkredit, kapitalforvaltning, værdipapirhandel og investeringsfonde i Danmark (Finans Danmark) og det andet med en privat nyetableret aktør (Lunar) finder vi at det er samarbejdet om den digitale infrastruktur, som er en væsentlig byggesten for fintech entreprenørskab i Danmark. 


\section{Oversigt}

I de følgende afsnit redegør vi for artiklens teoretiske greb og metode - og via refleksioner på digitale udviklinger og dialog med interviewpersoner, peger vi på samarbejdet i de underliggende samfundsstrukturer, som værende omdrejningspunktet for den danske model af den digitale innovation i Danmark. Vi fremhæver eksempler på dette mellem de etablerede banker på det danske marked og den nye digitale bank Lunar. Heri diskuterer vi begrebet bricolageprocesser i forhold til entreprenørskabssamarbejde og institutionel innovation, som kan forandre strukturer i et organisatorisk felt.

\section{B. Teoretiske greb}

\section{Institutionelle strukturer}

Når vi her anvender begrebet strukturelle styrker, så tager vi udgangspunkt i institutionel teori, som fokuserer på institutioners betydning for samfundets økonomiske, politiske og sociale udvikling. Institutionel teori kan ses som alternativ til behaviorisme og den neoklassiske økonomi, der har domineret samfundsvidenskab siden efterkrigstiden. Disse modsatte teorier ser individers og gruppers adfærd og interesser som primære variable, mens institutioner ofte opfattes som afledte eller irrelevante fænomener. Institutionel teori anskuer derimod institutioner som fænomener, der har afgørende betydning for menneskelig adfærd og sociale processer. Institutionel teori peger derfor (i modsætning) på samfundets institutioner, som formelle og uformelle forhold, der rammesætter og understøtter individuel og kollektiv handlen.

Den analysetilgang som denne artikel tilbyder, er derfor mere end det simple perspektiv på entreprenørskab, som et handlende individ eller som én virksomhed, der alene er innovativ. Den tilbyder inddragelsen af den sociale samfundsmæssige organisering og de samarbejdsmuligheder, som formelt og uformelt understøtter den digitale innovation og teknologiske udvikling. Kritikken er ikke ny, den er blot ikke mainstream. Den kan føres tilbage til Thorstein Veblen's (1899) kritik af neoklassisk økonomi, som havende et manglende perspektiv på den indflydelse, som teknologier og institutioner har på f.eks. de sociale og økonomiske uligheder.

Institutioner består følge Richard Scott (2008) af tre typer: kognitive, normative og regulative strukturer, som understøtter og skaber mening og stabilitet i al social adfærd i vores samfund (Scott, 2008). De kognitive strukturer vedrører de kulturmæssige forståelser og grundlæggende antagelser. Indenfor bankverdenen kan vi nævne forbrugerens forståelse af bankservices. Hvor man i tidligere tider forstod en bank som et fysisk sted med kasser og bankrådgivere bag disken, er det i dag blevet et virtuelt mødested såsom en online platform med ens private side, som man logger sig ind på via en PC eller en applikation på ens telefon. De normative strukturer omfatter derimod, hvad der er 
korrekt eller passende adfærd i en given situation. Ofte vil bankvirksomheder støde på forskellige former for sanktioner, hvis de ikke følger gængse normer, som afspejler et særligt værdisæt. Her kan vi nævne de seneste skandaler med hvidvasksager, overrente på investeringsporteføljer eller de digitale inkassoer, hvor tilbagebetaling har været sat for højt. Disse omfatter også normer omkring samarbejde i finanssektoren og bankverdenen, både internt i industrien, men også med en lang række offentlige organisationer i offentligt-privat samarbejde. Slutteligt er der regulative strukturer, hvilket omfatter formelle etablerede regler, lovgivning og kontrakter, der f.eks. sætter rammerne omkring offentligt-privat samarbejde, så som udviklingen af NemID og digital tinglysning, men også reguleringen af, hvordan offentlige data kan og må anvendes, og af hvem. De kognitive, normative og regulative strukturer skabes og udvikles løbende i et sammenspil mellem de aktører og centrale interessenter i et givent institutionelt felt (Lawrence \& Suddaby, 2006; Scott, 2008), her den finansielle sektor.

Når vi her i artiklen ser på digital innovation i den finansielle sektor, anskuer vi det som værende en form for institutionel innovation, hvilket defineres som "nye, nyttige og legitime forandringer, der i varierende grad ændrer og forandrer de kognitive-, normative- og regulative grundpiller i et organisatorisk felt. Institutionel innovation er som al innovation både nyt og nyttigt, men det adskiller sig ved også at være legitimt, troværdigt og hensigtsmæssig” (Raffaelli \& Glynn, 2015, oversat af forfatterne). Vi argumenterer senere i artiklen for, at det er de strukturelle faktorer, som danner grundlaget og fundamentet i finanssektorens innovationsøkosystem.

\section{2. Økosystem, samarbejdsdrevet entreprenørskab og bricolage}

I de sidste par år har der været en stigende interesse for begrebet "økosystemer" som en ny måde at skildre det konkurrenceprægede miljø på. Ifølge Jacobides, Cennamo \& Gawer (2018) i artiklen 'Towards a theory of ecosystems", så deler praktikere begejstring for ordet økosystemer: I prospektet for 2014 til verdens største børsintroduktion til dato, Alibaba, viser ordet økosystem sig ikke mindre end 160 gange. Begrebet går derfor ind i ordforrådet ikke kun for teknologifirmaer, men også for de etablerede sektorer, såsom den finansielle sektor.

Med økosystemtankegangen på digital innovation tager vi afsæt i Adner's (2017: 40) definition på entreprenante økosystemeri (frit oversat til dansk af forfatterne); at der sker en form for gensidig tilpasning imellem forskellige og løst koblede aktører, som gennem denne interaktion tilsammen skaber ny værdi i eksisterende services. Tænkegangen går fint i spænd med de offentlige ledelsesparadigmers sameksistens mellem New Public Management, som for alvor sætter fokus på den offentlige innovation ud fra et konkurrencemæssigt perspektiv, men mødes af bureaukrati og regler, som de forsøger at fjerne. Og New Public Governance, som peger på nøglen til at fremme offentlig innovation er gennem polycentriske samarbejder i netværk og partnerskaber (Ricard et.al. 2017; Torfing \& Ricard 2017). Sidstnævnte viderebringer et fokus på den samarbejdsdrevne 
innovation, hvordan offentlige og private aktører gennem netværk og partnerskaber kan arbejde sammen på at definere fælles problemer og udfordringer - og derigennem kan hver aktør i åbne netværk - og via egne samarbejder med for eksempel startup virksomheder udvikle nye og innovative løsninger til fremme af den digitale innovation.

Med anvendelse af økosystem-tankegangen og den finansielle sektor som værende indlejret i stærke offentlige forvaltningsstrukturer: både kognitive, normative og strikse regulativer kommer vi efterfølgende frem til relevansen af bricolage-begrebet, hvor aktører i form af at sammensætte eksisterende produkter og services på nye måder formår at skabe digital innovation. I netop den finansielle sektor er det nødvendigt, at innovation ikke udelukkende er ny og nyttig (traditionel innovation). Det er i høj grad også vigtigt, at innovation er legitim, trovoerdig og hensigtsmoessig (institutionel innovation), da den finansielle sektor i særlig høj grad er præget af offentlig forvaltning; af strikse normer og regler, som skal efterleves. Bricolage-begrebet er relevant i denne kontekst, da innovation ses som en proces, der griber entreprenørskabsmuligheder og blander tidligere tiders ressourcer og ideer på nye måder.

Bricolage blev introduceret af Lévi-Strauss (i 1962) til at beskrive den spontane designproces, hvormed aktører skaber nye løsninger ved at anvende forhåndenværende midler og ressourcer (LeviStrauss, 1962/66). I la pense suvage stiller Levi-Strauss ingeniøren overfor le bricoler. Bricoleren er en 'altmuligmand', der er i stand til at udføre en lang række forskelligartede opgaver og projekter. Han eller hun trækker på sin viden og de eksisterende ressourcer, som er til rådighed. Bricolerens princip er altid, at hun indretter sig efter de forhåndenværende midler, altså anvender det værktøj og de materialer, der findes i dennes afgrænsede samling. Samlingen består af diverse ressourcer og ideer, brugt i tidligere projekter. Hver enkelt ressource er nøje udvalgt ud fra sit potentiale, altså at "det kan man altid få brug for". Det vil sige, at man ikke har brug for alle professioners specialiserede viden og udstyr på én gang, men at ressourcer knyttes til specifikke og afgrænset anvendelse (Levi-Strauss 1962/1994; side 27). I dag kunne man drage parallel til, hvordan vi udvikler vores netværker og tilegner os ny viden, "det er ikke hvad du ved, men hvem du ved, som ved det" i visheden om at kunne bruge netværksressourcer i fremtiden. Det er således interaktionen med konteksten, der er vigtig her, og evnen til at omsætte de særlige strukturer og muligheder til entreprenørskab.

Essensen er, at entreprenørskaben her sker igennem en proces, der omfatter at omfordele og blande tidligere tiders ressourcer, praksisser og ideer på nye måder (Douglas, 1986, side 66-68; Campbell, 2004, side 69; Schneiberg, 2007; Garud and Karnøe, 2003). Der er tre nøgleelementer i bricolageprocessen: Repertoire, dialog og resultat. Repertoire kan bestå af både materielle og immaterielle ressourcer og være indsamlet uafhængigt af hinanden, fra tidligere tiders afsluttede projekter. Bricolage processen starter og slutter ved denne samling af ressourcer som i en cirkulær 
proces. Hver ressource udgør en række mulige koblinger, som kan sammensættes og udbygges på en række forskellige måder. Det er således en væsentlig pointe, at alt, hvad der bygges og skabes af disse ressourcer, bygger videre på etablerede modeller og resultater. Selve sammensætningen af ressourcer kan ses som en form for dialog (Duymedjian and Rüling, 2010), hvor udvælgelsen er bestemt af individers præferencer, kollektive interesser imellem organisationer og i netværkets økonomiske rammer, tekniske dimensioner, tid og rum (Colombero, 2015) og spiller derfor sammen med en form for udvælgelse af de kognitive strukturer i sammensætningen af samarbejdende. Det, der kendetegner en bricolage-løsning, er at man ofte vil være i stand til at se resultatet som en ny sammensætning af elementer (Lévi-Strauss, 1962/66; Duymedjian and Rüling, 2010) - og derfor afspejles både proces og det endelige resultat af en form for genopfindelse, som vi finder relevant for netop digitalisering. Med et institutionelt perspektiv på digital innovation lægges der særligt vægt på, at selve innovations-processen i høj grad er indlejret i meningsskabende, samarbejder mellem de etablerede virksomheder og politiske aktører og fremkomsten af nye entreprenante aktører i den underliggende struktur, som skaber grobetingelser for udvikling af digitale services. Det ér ideen om økosystemer, som tilbyder en ny måde at skildre det konkurrenceprægede miljø på.

\section{Metode}

\section{Udvælgelse af sektor og case}

Danmark har som nævnt en førende position i forhold til digitalisering. For at se nærmere på, hvad der muliggør digital innovation i Danmark, valgte vi at fokusere på en af de mest fremmelige sektorer, den finansielle sektor, der længe har illustreret en helt særlig drivkraft (som vi illustrerede i vores indledning). Vi valgte således denne sektor som en ekstrem case (Flyvbjerg, 2004; Eisenhart 1989), der kan give indblik i, hvad det er der udgør kernen i den danske model i forhold til digital innovation. For at konkretisere denne model har vi yderligere udvalgt Lunar bank som en illustrativ case, da denne tydeliggør nogle af elementerne i bricolage og samarbejdsentreprenørskab i den finansielle sektor. Lunar er en bank, der udelukkende er digital, dvs. udelukkende online tilstede via deres applikation og ejer ingen fysiske filialer. Lunar startede ud som en Fintech virksomhed med Nykredit som partner, det vil sige, at deres kunder reelt set var bankkunder i Nykredit. Dette har dog ændret sig i foråret 2020, da Lunar som den første Fintech i Danmark har fået en banklicens og dermed blevet etableret som en selvstændig bank i foråret 2020. De har i dag over 300.000 brugere i Danmark, Sverige og Norge. På nogle måder er Lunar en paradigmatisk case, idet den som case illustrerer mere generelle tendenser på samarbejdet i netværk og partnerskaber i den finansielle sektor. Men Lunar er samtidig den første fintech i Danmark, som har fået en banklicens, og skiller sig på digital innovation, da Lunar med deres nye digitale løsning er blevet godkendt af det etablerede system; Finanstilsynet. Lunar kan derfor ses som en kritisk case (Flyvbjerg, 2004), der gør det muligt at tale om institutionel innovation. Det skal dog med forbehold nævnes, at det stadig 
er uklart, om Lunars forretningsmodel og deres digitale innovationen er en reel succesfuld case på den lange bane, da de endnu ikke har haft et overskud (datacvr.virk.dk, 2020).

\section{Data, kilder og begrænsninger}

Denne artikel er primært udarbejdet på baggrund af dokumenter fra den finansielle sektor, herunder rapporter og hjemmeside information fra Finans Danmark, Innovations Fonden og SIRIKommissionen og Copenhagen Fintech (tilsammen omkring 300 sider). Desuden er der udført to ekspert interviews i september 2019. Det ene interview er med Michael Busk, som er digitaliseringschef i Finans Danmarks og dermed bidrager med ekspertindsigt i de forhold, der gør sig gældende for digital innovation i den finansielle sektor. Det andet interviewet er med Peter Smith, som er bankdirektør for den nye og hastigvoksende digitale bank 'Lunar'. Peter Smith bidrager med et indblik i de innovationsprocesser, som organisationen arbejder med i forbindelse med udviklingen af deres digitale services og produkter. Desuden trækker empirien på en præsentation af Lunar i 2019 hos CBS Startup Hub på Copenhagen Business School med adgang til præsentationen. Studiets metodiske tilgang og data har visse begrænsninger og er således ikke et videnskabeligt empirisk studie, men mere en reflekterende udforskning af de underliggende strukturer og aktørtyper, som gør sig gældende for digital innovation i den finansielle sektor. Vores valg af case og dataindsamling har således muliggjort udviklingen af denne konceptuelle artikel, som ud fra et institutionelt perspektiv bidrager med en synliggørelse af de særlige strukturelle styrker og processer, som danner grobund for digital innovation i den finansielle sektor i Danmark.

\section{Samarbejdsdrevet entreprenørskab af digital innovation}

\section{Den danske model}

Med udgangspunkt i vores observationer af den finansielle sektor, argumenterer artiklen for, at digital innovation i den finansielle sektor sker på grundlag af en særlig form for samarbejdsdrevet entreprenørskab, der bygger på scerlige strukturelle styrker i den danske model og som skabes igennem en 'bricolage proces', hvor eksisterende ressourcer genanvendes på nye måder og i nye konstellationer. Nedenfor gennemgår vi først de særlige innovationsstrukturer i den finansielle sektor, og derefter skitserer vi bricolagebegrebet med udgangspunkt i den digitale bank 'Lunar' som en illustrativ case.

Der findes mange strukturelle styrker i den danske model, som kan eksemplificeres med udviklingen og implementering af digitale flagskibe som NemID og MobilePay, som er blandt de mest udbredte fintech services blandt danske borgere. Fælles for disse digital innovationers succes er et sammenspil mellem offentlige og private aktører i arbejdet med entreprenører og startup virksomheder. 
Når man ser på de faktuelle faktorer, som styrker digital innovation i figur 4: bankernes tradition for samarbejde, offentligt-privat samarbejde, anvendelsen af grunddata, bankernes ekspertise i databehandling, og de digitale forbrugere, så bliver det tydeligt, at en fællesnævner er samarbejde omkring digital innovation, både indenfor finanssektoren, men også igennem offentligt-privat samarbejde. Det perspektiv underbygges af den forståelse, som vi finder i vores interview med Michael Busk, Digitaliseringschef i Finans Danmark:

"Det er frugtbart, og det er klogt for både store og mellemstore og små at arbejde sammen om at gøre de her innovationsgrænseflader endnu mere produktive, så det er godt for alle, at der sker noget i det område." (Interview med Michael Busk, digitaliseringschef Finans Danmark, 20 september 2019).

I figur 4 opdeler vi disse faktorer, som eksemplificerende for en kategorisering af institutionelle strukturer. 
Bankernes tradition for samarbejde omkring kerneinfrastruktur (primcert normative strukturer)

- De fællesejede datacentraler (BEC, SDC og Bankdata) leverer IT platformene til bankerne, samt den finansielle infrastruktur, det netværk, der binder bankerne sammen og muliggør betalinger og overførsler mellem banker

- Øvrige centrale aktører i kerneinfrastrukturen inkluderer Finans Danmark, e-nettet, Finanstilsynet, NETS og Danmarks Nationalbank

Offentligt privat samarbejde (primcert regulative og normative strukturer)

- Eksempelvis omkring Digital signatur/NemID-login (MitID), Digital Tinglysning og Copenhagen Fintech

Offentlige grunddata af høj kvalitet (primcert regulative strukturer)

- CPR-registret og andet offentlig data er af enestående høj kvalitet

Bankernes årelange ekspertise i databehandling (primcert normative strukturer)

- Danske virksomheder og banker har med deres årelange ekspertise med databehandling, og udvikling af digitale løsninger et stærkt udgangspunkt

Digitale forbrugere (primcert normative og kognitive strukturer)

- Danske forbrugere er blandt de mest digitale i verden, og danskere tager hurtigere og hurtigere nye digitale løsninger til sig

- Forbrugerne efterspørger digitale løsninger, der tager udgangspunkt i brugerens egne data (herunder offentlig grunddata)

Figur 4: Oversigt over eksemplificerende strukturelle faktorer, som styrker digital innovation

Trods en konservativ branche, så ser vi ifølge Michael Busk, digitalisering i finanssektoren, som en transformation, der opstår i samspillet imellem etablerede banker og virksomheder, startups og scaleups, i en form for innovationsøkosystem, som en transformation af den finansielle sektor. Èt initiativ, som direkte udspringer fra offentligt-privat samarbejde om samme sag er etableringen af Copenhagen Fintech - en hub for entreprenører med digital tech og service som omdrejningspunkt. Det er Finans Danmark, som sammen med Finansrådet og Københavns Kommune etablerede Copenhagen Fintech med en vision om at udvikle København, som et af de førende Fintech hub i verden ved at støtte og accelerere den næste generation af teknologi-drevne entreprenører (Copenhagen Fintech, 2019).

Fra Finansrådet og politikerne i Københavns Kommunes side ønskede man at understøtte det økosystem, der allerede var under udvikling, for at bringe de mange forskellige aktører sammen og 
få de digitale innovationer til at udvikle sig. I modsætning til meget liberal økonomiteori, står regulativer ofte som en rolle, staten alene påtager sig med det formål at overregulere og som en begrænsning for det frie marked, så ses for eksempel politikernes rolle i Danmark, som mere proaktive på at fremme digitalisering. De bidrager aktivt til udviklingen ved at indgå i et samarbejde med etablerede virksomheder og fintech startups, hvor de varetager rollen som forandringsagenter. En rolle, hvor de trækker på både de kognitive, normative og regulative strukturer i deres erhvervsfremmende entreprenørskabsaktiviteter til at understøtte digital innovation. Det vil sige, at den forståelse, som man har i sektoren om udviklingen i finanssektoren i forhold til fintech er, at det er en proces, som skaber en øget dynamik i branchen, hvor man samarbejder, opkøber og investerer i udviklingen af fintech løsninger og nye digitale servicemodeller (for at skabe kommercialiseringen af disse). Hermed er der en kulturel forskel på de Nordiske lande, ikke blot i forhold til USA, men på resten af Europa, forklarer Michael Busk, Digitaliseringschef i Finans Danmark. Han hævder i vores samtale, at vi i Norden er meget mere åbne for ny ideer og sindet omkring at arbejde sammen, de etablerede spillere og fintech startup imellem:

"Hvis du tager til Frankrig, vil du finde meget hårdere brudflader imellem de etablerede spillere og startup virksomheder. Der er vi bedre til, hvis det er godt at være inkluderende og arbejde tæt sammen. Vi er meget pragmatiske, og hvis der er nogen, der kommer med noget, der er klogt, jamen så er det jo klogt, uanset om det er en idé fra en lille startup virksomhed. Jeg tror, at vi har meget respekt for den gode idé: 'Hey, det er smart, det skal vi gøre'. Det er ikke sådan, at det vil vi kun gøre, hvis det kommer fra IBM. Der synes jeg, at branchen er ret åben over for nye ideer i Danmark, generelt" (Interview med Michael Busk, digitaliseringschef Finans Danmark, 20 september 2019).

Dette betyder dog ikke, at der ikke er konservatisme eller direkte markedskonkurrence i finanssektoren, men mere, at virksomhederne i modsætning til at fastholde status quo og konkurrere på produktudvikling, i stedet søger at samarbejde om de digitale strukturer og differentiere sig igennem de digitale serviceløsninger, som virksomhederne har at tilbyde kunderne, fordi, mulighederne for at differentiere sig er fuldstændig afhængig af den grundlæggende infrastruktur, som bankerne og finanssektoren har opbygget i fællesskab. Det er her, at fintech og entreprenørskab kommer ind i billedet. Fintech startup virksomheder opstår i økosystemer, hvor der er behov for langt mere agilitet, end de etablerede spiller kan tilbyde. Ikke nødvendigvis, at de skal ses som disruptive, mere at der opstår muligheder for at arbejde med det etablerede system på nye måder og bygger nye løsninger og koblinger oven på det eksisterende system. En organisationsegenskab, som vi kender som bricolage og er relevant, hævder vi, til at forstå den digitale innovationsproces, vi ser i finanssektoren i dag. 
Med bricolage-perspektivet på digitalisering lægges der særligt vægt på at innovation, og selve bricolage-processen i høj grad er en situeret kontekst specifik aktivitet, der er drevet at entreprenante aktører. Særligt i forhold til informationsteknologi og -systemer er bricolagekonceptet relevant, da disse er karakteriseret af en høj grad af fleksibilitet i anvendelsen. Informationssystemer har en diversitet, der i den grad muliggør, at man opbryder, omrokerer og rekombinerer systemerne, hvilket netop kendetegner bricolage (Duymedjian and Rüling, 2010).

Informationssystemerne har en helt central funktion i banksektoren, og for eksempel fremhævede Peter Smith, bankdirektør for Lunar, at "bankerne reelt set er IT-selskaber med filialer" (Interview, 19 september 2019). Dette er med til at underbygge en antagelse om, at den digitale innovation i sektoren sker igennem en bricolage-proces, situeret i et særligt dansk innovationsøkosystem.

Nedenfor vil vi med udgangspunkt i en illustrativ case, den digitale bank Lunar, skildre bricolageprocessen.

\section{Bricolagebegrebet i processen hos den digitale bank Lunar}

Et konkret eksempel samarbejdsdrevet entreprenørskab ved hjælp af bricolage-innovation er den digitale bank Lunar (tidligere Lunar Way). Lunars bank applikation repræsenterer en innovativ bankløsning med flere integrerede produkter, der bygger på partnerskaber. Lunar-casen er valgt da den tydeligt illustrerer det samarbejdsdrevne entreprenørskab der er i den finansielle sektor i forhold til digital innovation. Nedenfor viser vi vores centrale pointe omkring samarbejdsdrevet entreprenørskab ved at genfinde og skitsere de tre nøgleelementer i bricolage-processen, nemlig: repertoire (samlingen af ressourcer); dialog og løsning.

\section{a. Repertoire}

'Repertoire' eller samlingen af ressourcer er et centralt begreb i Lévi-Strauss' bricolage idé, og denne samling kan bestå af både materielle og immaterielle ressourcer, som er indsamlet uafhængigt af hinanden, fra tidligere tiders afsluttede projekter. Bricolage processen starter og slutter ved denne samling af ressourcer som i en cirkulær proces. Hver ressource udgør en række mulige koblinger, som kan sammensættes og udbygges på en række forskellige måder. Det er således en væsentlig pointe, at alt hvad der bygges og skabes af disse ressourcer, bygger videre på etablerede modeller og resultater. I vores case ser vi, at fintech virksomhederne og Lunar anvender og videreudvikler de ressourcer, der er opbygget kollektivt i industrien igennem en lang årrække. Herunder løsningerne fra en af de fællesejede datacentraler (BEC), NemID, BankID og Nets. Mere specifikt så ser vi, de førnævnte strukturelle styrker (figur 4) som de væsentligste elementer i finanssektorens fælles 'repertoire'. De enkelte aktører har mulighed for at anvende ressourcerne igennem en 'dialog' proces. 


\section{b. Dialog}

Sammensætningen af ressourcer kan ses som en form for dialog, hvor udvælgelsen er bestemt af individers præferencer, kollektive interesser imellem organisationer og i netværket, men også er præget af de økonomiske rammer og tekniske dimensioner i tid og rum (Colombero, 2015). Hos Lunar ser vi blandt andet, at virksomheden har adgang til netværket ved at have bestyrelsesmedlemmer med stærke rødder industrien, herunder Henning Kruse, som er både tidligere koncernchef for Nykredit og tidligere formand for Finansiel Stabilitet; Jens Peter Leschly Neergaard, som er tidligere direktør for Danske Bank Markets og Danske Banks internationale aktiviteter; og bankdirektøren Peter Smith, som er tidligere direktør for Nordea Kredit, samt, har været involveret i samarbejde med Nets og Finans Danmark. Disse centrale aktører i Lunar har således en indgående forståelse af det etablerede system og den samling af ressourcerne (repertoire), der eksisterer. Samtidig så har Lunar en IT-start-up mentalitet, da virksomheden er stiftet af iværksætteren Ken Villum Klausen, der har grundlagt flere startups, herunder Wallmob, en digital betalingsløsning der kan anvendes på mobile enheder. Den daglige ledelse er ligeledes sammensat af folk med stærke baggrunde fra tech, operations, compliance, produkt og marketing (Lunar, 2020). Lunar har således en sammensætning af aktører, som kombinerer IT-teknologikultur med nye digitale modeller og etablerede strukturer i finanssektoren.

\section{Partnerskaber - Infrastruktur}

- BEC (Fællesejet datacentral) - Clearing - kontobetalinger og overførsler

- AWS (Amerzon Web Service) - Cloud computing solution

- Nets - alle processer omkring betalinger

- VISA - Debitkort løsning

- NemID + BankID - Identifikationsdokument (ID)

- TEMENOS - Hvidvaskmonitorering

- Nykredit - Kerne bankinfrastruktur til egen bank etableret i foråret 2020, med overgangen fra FinTech til etableret selvstændig bank, med egen banklicens

\section{Partnerskaber - Produkter og serviceydelser}

- Saxo Bank - Aktiehandel applikation

- Tryg - Forsikring til kunder igennem applikation

- Basislån - Lån

- Dinero - Regnskabsintegration for erhvervskunder

- Billy -Regnskabsintegration for erhvervskunder

- Qred - Lån til erhvervsdrivende

- E-economic - Regnskabsintegration for erhvervskunder

Tabel 2: Oversigt over Lunars nøglepartnerskaber - grundlag for forretningsmodellen (Lunar 2020) 
Lunar bygger ikke ny og radikal innovation, men ny applikation på baggrund af det eksisterende banksystem og samarbejder med etablerede spillere i den finansielle sektor såsom Nykredit, Saxo Bank og Finans Danmark for at levere en ny digital pallette af løsninger til deres kunder (se tabel $2 \mathrm{og}$ figur 5, for en oversigt over deres partnerskaber). Ligesom de øvrige danske banker så er Lunar, eksempelvis afhængige af de fællesejede datacentraler, i deres tilfælde BEC, for at få adgang til den finansielle infrastruktur, der eksempelvis muliggør deres kunders betalinger og overførelser. Nets står for alle processer omkring betalinger, og Visa står får deres debit-kort løsning. Den infrastruktur Lunar bygger på er således de etablerede systemer fra finanssektorens repertoire.

I udviklingen af deres produkter og serviceydelser så har Lunar endvidere indgået en række partnerskaber med forskellige aktører fra finanssektoren og fintech miljøet. Langt de fleste er ligesom Lunar også partnere, sponsorer eller medlemmer af Copenhagen Fintech. Disse partnerskaber muliggør Lunars forretningsmodel og deres digitale bankløsning.

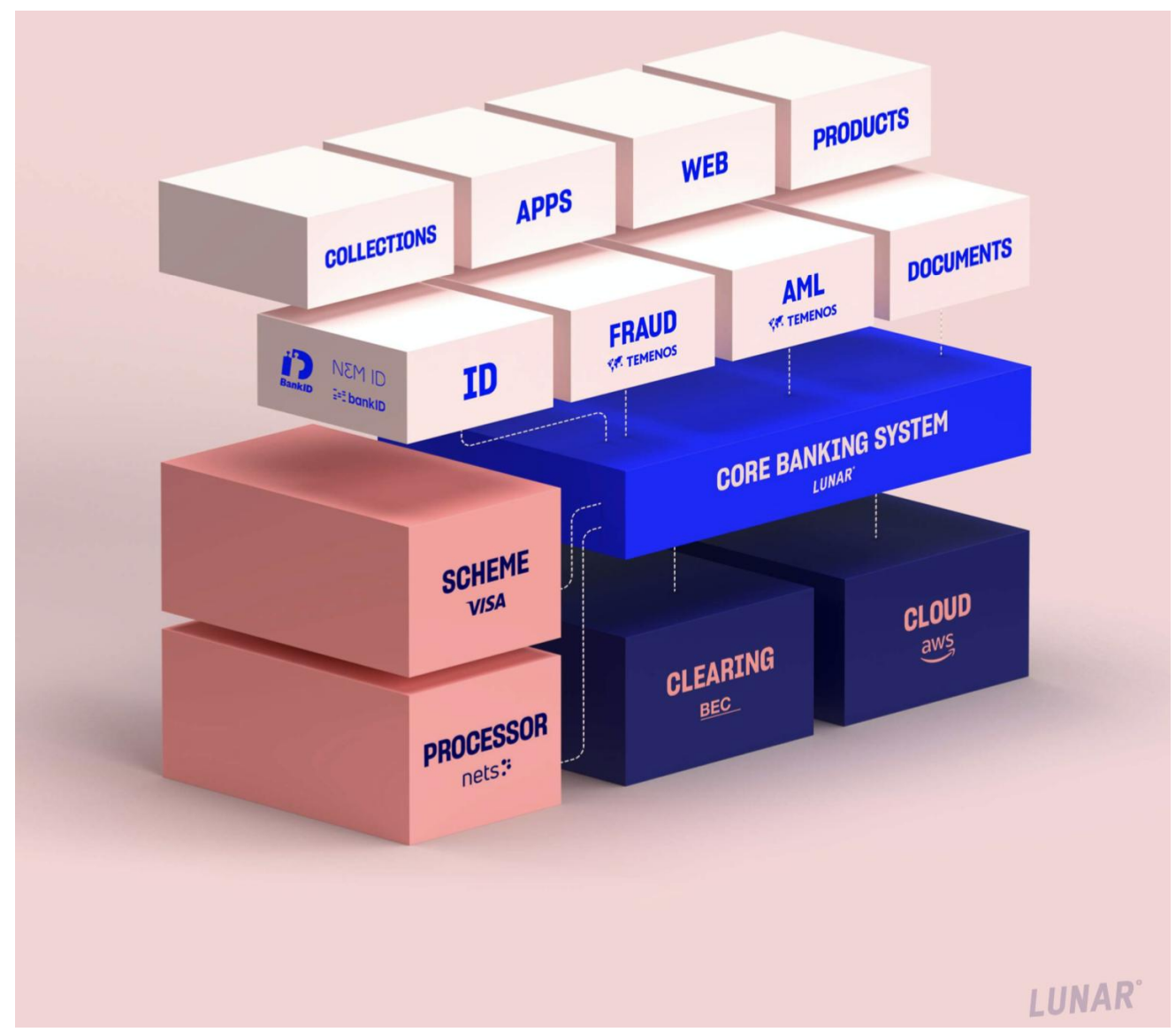

Figur 5: Lunars eget partnerskabsoverblik baseret på byggesten i forretningen (Lunar, 2020)

\section{c. Løsning}


Begrebet bricolage karakteriserer både processen og det endelige resultat. Det, der kendetegner en bricolage-løsning, er at man ofte vil være i stand til at se resultatet, som det det er, nemlig en ny sammensætning af elementer (Lévi-Strauss, 1962/66; Duymedjian and Rüling, 2010). I Lunarcasen er det endelige resultat, en digital bankløsning, hvor Lunar tilbyder en række selvstændige produkter i deres applikation, såsom; lån i samarbejde med BasisBank; rejseforsikring i samarbejde med Tryg forsikring; velgørenhed i samarbejde med Røde Kors og et aktieinvesteringsprodukt i samarbejde med Saxo Bank (se figur 6 med overblik over produktapplikationer). En række af de produkter, som Lunar tilbyder deres kunder, er således noget, der er skabt via en ny-kobling af eksisterende systemer og modeller, der bringes sammen inden i en ny platform, Lunars applikation. Uanset partnerskabet og de selvstændige digitale produkter, oplever kunden paletten af produkter inde i Lunar's digitale-bankunivers, som én samlet løsningsmodel. 


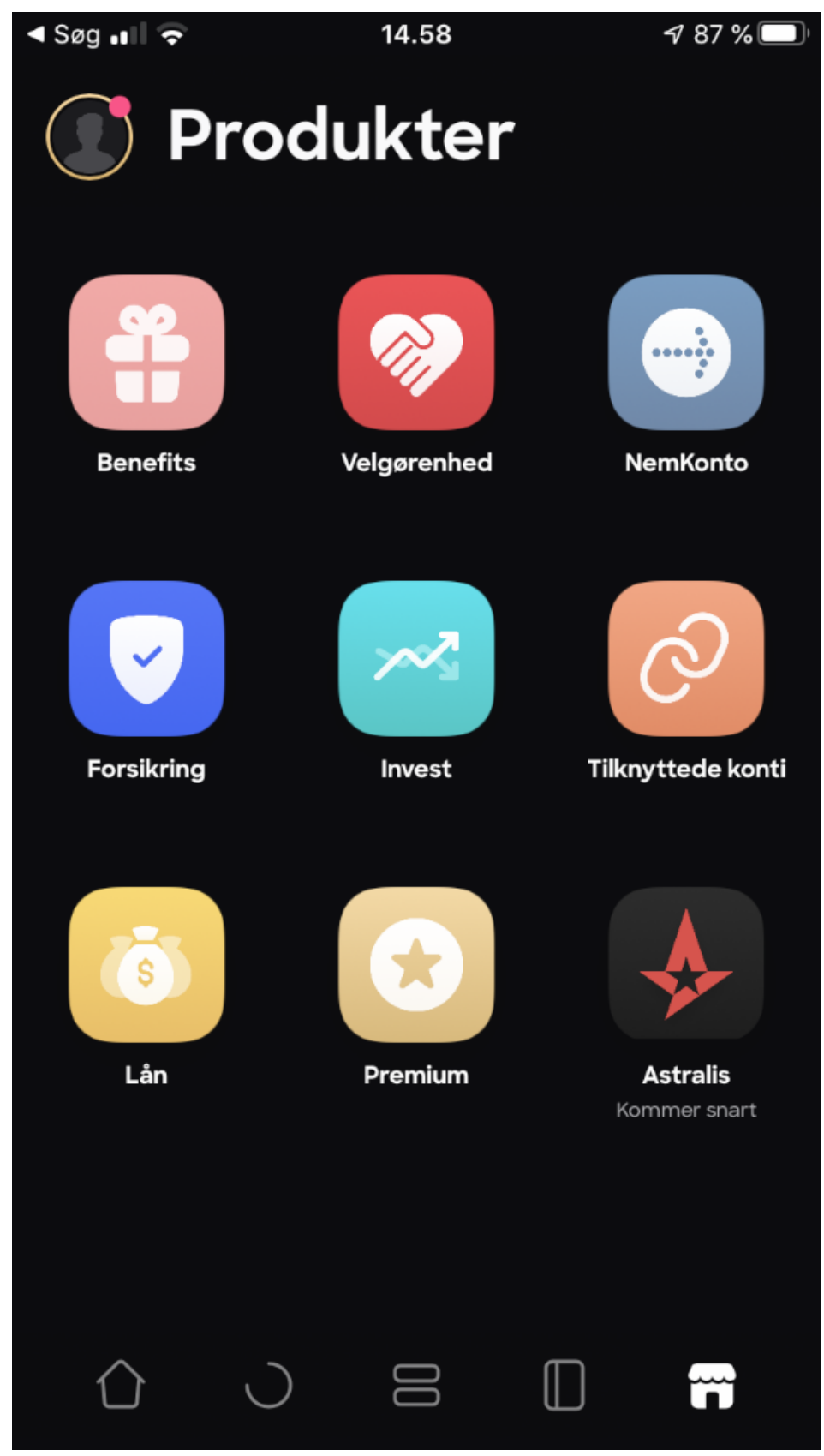

Figur 6: Overblik over produktapplikation hos Lunar (2020)

Der, hvor innovationsprocessen i denne case, adskiller sig fra traditionel konkurrencedrevet innovation, er, at denne i høj grad er samarbejdsdrevet. Det er således ikke enkelte entreprenante individer alene, som skaber den digitale innovation, men et netværk. Et økonetværk af aktører, der skaber digital innovation - og som er afhængig af den sociale kapital, som ligger i de understøttende institutionelle strukturer. Det øgede fokus på digital innovation i banker gør, at sektoren opdager et behov for at arbejde mere agilt med innovation. Det skaber samarbejde på tværs af professioner; IT, forretning og bankservice, fordi de etablerede virksomheder er kendt for ikke at kunne udvikle eller omstille sig så hurtigt, og ofte heller ikke tage så store risici, som de mindre fintech startups. 
På den måde kan man holde risikoen uden for den normale bankdrift, men være klar til at ibrugtage den og kommercialisere nye digital services, som de etablerede banker er rigtig gode til. Udover de strukturelle kompetencebehov er der så også nogle særlige netværks-/ og ledelseskompetencer, som gør sig gældende og på den måde bliver mere synlige.

"Den agilitetsrejse tror jeg er generel for hele sektoren som i mange andre sektorer. Og det stiller nogle andre krav til de medarbejdere, der er der i dag end dem der var der for 10-15 år siden [...] I dag foregår al udvikling jo i sådan nogle teams eller squats, så du skal kunne tale med en udvikler eller selv være udvikler. Bankerne er reelt set IT-selskaber med filialer. Derfor er der et behov for medarbejdere, der kan agere i en bankforretning og samarbejde med ITudviklere. Man er gået væk fra ideen om "oversættere”. I stedet skal den enkelte medarbejder selv være i stand til at forstå hvordan forretningen fungere fra et teknologisk perspektiv. For eksempel så kan det godt være vores udviklingschef ikke selv kan kode, men hun eller han kan agere med et team af IT-udviklere og kan nok teknologi til at kunne tale med om projektet og løse de udfordringer, der måtte være. De folk, der forstår begge dele (IT og bankforretning) og kan sidde med et team af IT-udviklere og få komplekse finansielle opgaver løst, vil blive mere og mere eftertragtede" (Interview med Peter Smith, Head of Banking, Lunar, 19 september 2019).

Med dette blik på digital innovation, ligges der særligt vægt på at innovationsprocessen og selve bricolage-processen i høj grad er en situeret aktivitet, der er drevet af entreprenante aktører, som skal være mere agile end de store etablerede aktører. Men kompetencebehovsbeskrivelsen peger også videre på dér, hvor Danmark er ved at blive overhalet af både Finland og Sverige - på human kapital - at der er behov for at uddanne folk, som er mere tværfaglige end de traditionelle fag med opdeling i teknologi, finansiering og IT-uddannelser.

\section{E. Konklusion og perspektivering}

Denne artikel identificerer nogle af de væsentligste processer og strukturer omkring digital innovation i Danmark ud fra et institutionelt perspektiv. De vigtigste faktor, som artiklen peger på er:

1) At digital innovation i den finansielle sektor bygger videre på en mangeårig tradition for offentligt private samarbejde på digital infrastruktur, herunder udviklingen af NEMID, Digital betalingsservices som MobilePay, integrationen af teknologi, digitalisering af offentlige services - og herigennem at grundstenene til den digitale innovation bygger på en legitim og troværdig innovation (institutionel innovation). 
2) At den digitale innovation potentielt set kan udvikles i samarbejder, i netværk og partnerskaber mellem de etablerede virksomheder og startups som alternativ til ren konkurrencepræget markedsinnovation. Dvs. med de etablerede aktører, som kender de strukturelle kontekstuelle spilleregler; de kognitive, normative og regulative og har godkendte og sikre platforme til udbredelse.

Vi fremhæver eksempler på dette mellem de etablerede banker på det danske marked og den nye digitale bank Lunar. Heri diskuterede vi begreberne bricolage i forhold til entreprenørskabsdrevet samarbejde og økosystem i forhold til at se på de processer og strukturer, som vi igennem samtaler med centrale aktører peger på som værende omdrejningspunktet for den danske model af den digitale innovation i Danmark. Bricolage er relevant i denne kontekst, da innovation ses som en proces, der griber entreprenørskabsmuligheder og blander tidligere tiders ressourcer, ideer og kompetencer på nye måder. Af perspektivering vil vi pege videre på, at netop 'human kapital' er et af parametre i DESI indekset, som Finland og Sverige accelererer uddannelser - også her vil den danske model kunne bruges for at videreudvikle de tværfaglige kompetencer, som de nye digitale virksomheder efterspørger.

Afslutningsvis med dette institutionelle perspektiv på digital innovation, lægges der særligt vægt på, at selve innovationsprocessen i høj grad er indlejret i samarbejder mellem de etablerede virksomheder og netværkspolitiske aktører for at understøtte fremkomsten af nye entreprenante startups. Det er en underliggende struktur, som skaber grobetingelser for udvikling af digitale services. Perspektivet, som artiklen her tilbyder, er en udbygning af ideen om økosystemer med samarbejdsdrevet entreprenørskab i de underliggende strukturer, som unikke vækstbetingelser i fintech miljøet i Danmark. På denne måde tilbyder et institutionelt perspektiv en antitese til den traditionelle (neoklassiske) økonomis måde at skildre et konkurrencepræget markedsdrevet miljø på, hvor innovationsprocesserne er lukkede, og relationerne er anonyme. Med et neoklassisk innovationsperspektiv ville man i langt højre grad fokusere på de isolerede innovationsprocesser, uden blik for de sammenhænge disse indgår i. Man ville således ikke have blik for hverken historikken eller det økosystem hvor udviklingen af nyskabelsen sker - og man ville således ikke fange den institutionel innovation. Det vil sige de grundlæggende byggesten for den digitale infrastruktur med produkter, som opfattes som legitime, trovoerdige og hensigtsmoessige. Det er disse samarbejder, som danner grundlaget for den digitale innovation i Danmark- at forbrugere tager de digitale services til sig, samtidig med at der skabes incitamenter, regulativer og vejledninger.

\section{F. Tak til interviewpersoner}


Tak til Michael Busk, digitaliseringschef i Finans Danmark og Peter Smith, Head of Banking, i den digital bank Lunar, for at have stillet op til interviews i 2019. Yderligere tak til Lunar, for at have delt interne dokumenter.

\footnotetext{
${ }^{i}$ Adners definition på original sprog "the alignment structure of the multilateral set of partners that need to interact in order for a focal value proposition to materialize" (Adner, 2017:40).
} 


\section{Referencer}

Adner, Ron (2017). Ecosystem as Structure: An Actionable Construct for Strategy. Journal of Management. Volume: 43 issue: 1, page(s): 39-58 https://doi.org/10.1177/0149206316678451

Campbell, J. L. (2004). Institutional change and globalization. Princeton University Press

Colombero S. (2015) Instantiating through collective bricolage: the case of the Listed-Buildings Institution. Business administration. Ecole Nationale Supérieure des Mines de Paris, 2015. English.

Copenhagen Fintech (2019/2020) hjemmesiden: https://copenhagenfintech.dk senest besøgt 17.09.2020

Datacvr.virk.dk (2020) Data indhentet på Lunar Group ApS den 3 september 2020 via website. https://datacvr.virk.dk/data/visenhed?enhedstype=virksomhed\&id=36945745\&soeg=lunar\&type= undefined\&language $=$ da

Douglas, M. (1986). How institutions think. Syracuse University Press.

Duymedjian, R., \& Ruiling, C. (2010). Towards a foundation of bricolage in organization and management theory. Organization Studies, 31(2), 133-151.

https://doi.org/10.1177/0170840609347051

Eisenhardt, K. M. 1989 "Building Theories from Case Study Research." Academy of Management Review, 14(4): 532-550.

Europa-Kommissionen (2020) Digital Economy and Society Index. DESI Index. Hentet på: https://ec.europa.eu/digital-single-market/en/scoreboard/denmark 03.09.2020

Europa-Kommissionen (2020) International Digital Economy and Society Index 2020. Hentet på: https://digital-strategy.ec.europa.eu/en/policies/desi 16.08.2021

European Digital City Index (2016) Hentet fra: https://digitalcityindex.eu 03.09.2020

Finans Danmark (01.06.2017) Dansk betalingssystem på højt internationalt niveau. Hentet på: https://finansdanmark.dk/nyheder/2017/dansk-betalingssystem-paa-hoejt-internationaltniveau/ 03.09.2020

Finans Danmark (25.02.2019) Mobilepay sparer samfundet for millioner af kroner. Hentet på: https://finansdanmark.dk/nyheder/2019/mobilepay-sparer-samfundet-for-millioner-afkroner/ 03.09.2020

Finans Danmark (2017) 7 digitale ideer der styrker Danmark. Pdf hentet på: https://www.finansdanmark.dk/media/18794/7_digitale_ideer.pdf 26.08.2019 
Flyvbjerg, B. (2006). Five misunderstandings about case-study research. Qualitative inquiry, 12(2), 219-245. https://doi.org/10.1177/1077800405284363

Garud, R., \& Karnøe, P. (2003). Bricolage versus breakthrough: Distributed and embedded agency in technology entrepreneurship. Research Policy, 32(2), 277. https://doi.org/10.1016/s00487333(02)00100-2

Innovationsfonden (2019) Innovation Fund Denmark- Report of the International Evaluation Panel 2019. Rapport hentet fra: https://ufm.dk/publikationer/2019/innovation-fund-denmark-report-ofthe-international-evaluation-panel-2019 (dato 26.08.2019)

Jacobides, Michael G, Cennamo, Carmelo \& Gawer, Annabelle (2018). Towards a theory of ecosystems. Strategic Management Journal. Volume 39, Issue 8, 2255-2276.

https://doi.org/10.1002/smj.2904

Lawrence, T. and Suddaby, R. R. (2006) Institutions and Institutional Work. In Clegg, S., Hardy, C. \& W. R. Nord (Eds.) Sage Handbook of Organization Studies, 2nd Edition: 215-254. London: Sage., Available at SSRN: https://ssrn.com/abstract=3197577

Lévi-Strauss, C. (1962/1966). The savage mind [La Pensée savage] (Weidenfield, George and Nicholson Ltd. Trans.). University of Chicago Press.

Levi-Stauss, C. / Lund, H. P. (1962/1994) Den vilde tanke. Gyldendal.

MobilePay (2018) MobilePay passerer 4 millioner danske brugere. Hentet fra https://mobilepay.dk/nyheder/2018/12/06/mobilepay-passerer-4-millioner-danske-brugere 04.11.2019.

Raffaelli, R., \& Glynn, M. A. (2015). Institutional Innovation: Novel, Useful. In: The Oxford Handbook of creativity, innovation, and entrepreneurship, 407-420.

https://doi.org/10.1093/oxfordhb/9780199927678.013.0019

Ricard, Lykke Margot; Klijn, Erik Hans; Lewis, Jenny; Ysa, Tamyko (2017). Assessing public leadership styles for innovation: A comparison of Copenhagen, Rotterdam and Barcelona. Public Management Review, 19:2, 134-156. https://doi.org/10.1080/14719037.2016.1148192

Schneiberg, M. (2007). What's on the path? Path dependence, organizational diversity and the problem of institutional change in the US economy, 1900-1950. Socio-Economic Review, 5(1), 47-80.

Scott, W. R. (2008). Institutions and Organizations, Ideas and Interests, third edition. SAGE Publications

SIRI-Kommissionen v. Hanne Shapiro (2018) Fintech- en international kortloegning 2018. Rapport hentet på: https://ida.dk/om-ida/temaer/siri-kommissionen/siri-kommissionen-analyser-ograpporter 17.09.2019 
TechSavvvy (2019) Dansk fintech runder 1 milliard investeringskroner i år: "Vi har kun set toppen af isbjerget". Hentet fra https://techsavvy.media/dansk-fintech-runder-1-milliardinvesteringskroner-i-aar-vi-har-kun-set-toppen-af-isbjerget/ 03.09.2020.

Torfing, Jacob, Ricard, Lykke Margot (2017). Innovation - Samarbejdsdrevet innovation som alternativ til undtagelsesvis adhocrati og heroisk entreprenørskab (sider: 233-252) i bogen "New Public Governance på Dansk' (red. Torfing \& Triantafillou). Akademisk forlag. https://doi.org/10.1017/cbo9781316105337.001 